ISSN: 2302-8556

E-Jurnal Akuntansi Universitas Udayana

Vol.24.3.September (2018):2096-2120

DOI: https://doi.org/10.24843/EJA.2018.v24.i03.p17

\title{
Pengaruh NPL, LDR, dan CAR pada ROA Perusahaan Perbankan yang Terdaftar di BEI Tahun 2014-2016
}

\section{Putu Intan Trisna Dewi ${ }^{1}$ I Ketut Suryanawa ${ }^{2}$}

\author{
${ }^{1}$ Fakultas Ekonomi dan Bisnis Universitas Udayana (Unud), Bali - Indonesia \\ Email: intantrisna8@gmail.com / Telp:081236254262 \\ ${ }^{2}$ Fakultas Ekonomi dan Bisnis Universitas Udayana (Unud), Bali - Indonesia
}

\begin{abstract}
ABSTRAK
Perbankan mempunyai peranan penting dalam mempengaruhi kegiatan ekonomi. Perbankan dituntut untuk memperoleh keuntungan sehingga mampu bersaing demi mempertahankan kelangsungan hidupnya. Keuntungan tersebut digunakan untuk membayar semua jenis biaya operasional. Penelitian ini dilakukan di Perusahaan Perbankan yang Terdaftar di Bursa Efek Indonesia Periode Tahun 2014 - 2016. Jumlah sampel yaitu 20 bank, dengan metode teknik purposive sampling. Pengumpulan data yang dilakukan dengan cara observasi atau pengamatan. Teknik analisis yang digunakan adalah analisis regresi linear berganda. Berdasarkan hasil penelitian, diketahui bahwa non performing loan mempunyai pengaruh negatif padareturn on asset, loan to deposit ratio mempunyai pengaruh positif padareturn on asset, dan capital adequacy ratio mempunyai pengaruh negatif padareturn on asset.
\end{abstract}

Kata Kunci: Non Performing Loan, Loan To Deposit Ratio, Capital Adequacy Ratio, Return On Assets.

\begin{abstract}
Banking plays an important role in influencing economic activity. Banking is required to gain profit so as to compete in order to maintain its survival. The profit is used to pay for all types of operational costs. This research was conducted in Banking Companies Listed in Indonesia Stock Exchange Period Year 2014 - 2016. The number of samples is 20 banks, with the method of purposive sampling technique. Data collection is done by observation or observation. The analysis technique used is multiple linear regression analysis. Based on the result of research, it is known that non performing loan has negative effect on return on asset, loan to deposit ratio has positive effect on return on asset, and capital adequacy ratio has negative effect on return on asset.
\end{abstract}

Keywords: Non Performing Loan, Loan to Deposit Ratio, Capital Adequacy Ratio, Return On Assets. 


\section{PENDAHULUAN}

Perbankan mempunyai peranan penting dalam mempengaruhi kegiatan ekonomi, sehingga perbankan dapat dijadikan tolak ukur dalam perkembangan ekonomi di Indonesia. Perbankan mampu bersaing demi mempertahankan kelangsungan hidupnya, oleh karena itumenghasilkan laba merupakan sesuatu yang penting.Laba tersebut dapat digunakan untuk membayar segala jenis biaya-biaya operasional. Selain untuk menutupi kewajiban-kewajiban yang harus dibayarkan oleh perusahaan, keuntungan yang diperoleh dapat digunakan untuk berinvestasi dalam bentuk ekspansi perusahaan. Dalam pengambilan keputusan, mempertimbangkan perolehan laba merupakan hal yang sangat penting (Sianturi, 2012).

Profitabilitas pada umumya yang digunakan adalah Return on Equity (ROE) dan Return on Asset (ROA). Return on Asset (ROA) memfokuskan kemampuan manajemen bank dalam menghasilkan income dari pengelolaan aset perusahaan yang dimiliki (Dendawijaya, 2003). Dalam menentukan tingkat kesehatan bank yang pada akhirnya dapat mencerminkan keberlanjutan kinerja keuangan suatu bank, Bank Indonesia lebih mementingkan penilaian besarnya laba berdasarkan Return On Asset (ROA) karena Bank Indonesia lebih mengutamakan nilai profitabilitas suatu bank yang diukur dengan assets yang sebagian besar dananya dihimpun dari simpanan masyarakat (Dendawijaya, 2003). 
Non performing loan (NPL) merupakan rasio untuk mengukur besarnya tingkat kredit bermasalah yang terjadi pada suatu bank. Besarnya persentase NPL haruslah menjadi perhatian pihak manajemen karena kredit bermasalah yang semakin meningkat dapat membahayakan kesehatan bank tersebut. Bank yang memiliki non performing loan yang melebihi standar yang telah ditetapkan oleh Bank Indonesia akan menyebabkan penurunan profit yang diperoleh, karena semakin tinggi non performing loan maka semakin buruk kualitas kredit yang menyebabkan jumlah kredit yang bermasalah semakin besar, sehingga bank mengalami kerugian dalam kegiatan operasionalnya yang berpengaruh terhadap menurunnya laba yang diperoleh bank, sehingga dapat dikatakan bahwa NPL berpengaruh negatif dan signifikan terhadap profitabilitas (Manuaba, 2012).

Loan to deposit ratio (LDR) menyatakan seberapa jauh kemampuan bank membayar kembali penarikan yang dilakukan nasabah deposan dengan mengandalkan kredit yang diberikan sebagai sumber likuiditasnya (Sianturi, 2012). Penting bagi pihak manajemen untuk memperhatikan persentase rasio LDR tetap berada pada batas aman yang telah ditentukan oleh Bank Indonesia. LDR adalah perbandingan antara total kredit dengan total dana yang dihimpun, semakin besar rasio LDR mengindikasikan bahwa volume penyaluran kredit pada bank tersebut meningkat. Semakin besar volume penyaluran kredit akan meningkatkan profitabilitas bank karena bank memperoleh pendapatan melalui bunga kredit tersebut, sehingga dapat dikatakan bahwa LDR berpengaruh positif dan signifikan terhadap profitabilitas. Penelitian yang dilakukan oleh Agustiningrum (2013). 
Modal pada bank memiliki peran yang sangat penting. Kecukupan modal dapat diukur dengan menggunakan rasio CAR (Capital Adequacy Ratio). Penting bagi pihak manajemen untuk memperhatikan besarnya CAR yang dimiliki agar bank tidak kekurangan dana dan juga tidak kelebihan dana. Modal merupakan sumber utama pembiayaan kegiatan operasional bank dan juga berperan sebagai penyangga kemungkinan terjadinya risiko kerugian. Semakin besar modal yang dimiliki maka semakin kuat bank tersebut dalam mengahadapi risiko-risiko yang tidak terduga sehingga bank dapat meningkatkan kepercayaan masyarakat (Anjani dan Purnawati, 2014). Namun bank yang memiliki CAR terlalu tinggi dapat mengakibatkan terjadinya idle fund, yaitu terdapat banyaknya dana yang menganggur yang tidak dapat dimanfaatkan oleh manajemen bank tersebut. Modal bank terdiri dari modal inti dan modal pelengkap (Idroes, 2011). Berdasarkan Peraturan Otoritas Jasa Keuangan Nomor 15/POJK.03/2017, permodalan minimum yang harus dimiliki oleh suatu bank adalah $8 \%$.

Dari uraian latar belakang dan adanya ketidakkonsistenandari hasil penelitian yang menguji Non Performing Loan (NPL), Loan to Deposit Ratio (LDR) dan Capital Adequacy Ratio (CAR) terhadap Profitabilitas Bank(ROA) dan melihat fenomena di atas maka penelitian ini diambil dengan judul “ Pengaruh NPL,LDRDan CARTerhadap Profitabilitas Bank(ROA) Pada Perusahaan PerbankanYang Terdaftar Di Bursa EfekIndonesia PeriodeTahun 2014-2016". Berdasarkan latar belakang di atas, masalah yang dapat dirumuskan adalah sebagai berikut: (a) apakahnon performing loan berpengaruh terhadap 
return on asset?(b) apakah loan to deposit ratio berpengaruh terhadap return on asset? (c) apakah capital adequacy ratio berpengaruh terhadap return on asset?

Hasil penelitian ini diharapkan akan dapat bermanfaat untuk memperluas pengetahuan dan menambah wawasan mengenai pengaruh Non Performing Loan, Loan to Deposit Ratio dan Capital Adequay Ratio terhadap Return On Asset pada perusahaan perbankan yang terdaftar di Bursa Efek Indonesia (BEI). Selain itu penelitian ini juga bertujuan untuk mendukung temuan-temuan riset sebelumnya. Begitu pula Hasil penelitian ini diharapkan dapat digunakan sebagai bahan pertimbangan bagi pihak manajemen perusahaan perbankan di indonesia dalam mempertahankan/meningkatkan return on asset tersebut. Selain itu, hasil penelitian ini diharapkan dapat menjadi salah satu bahan pertimbangan masyarakat dalam menempatkan dananya pada bank-bank tersebut.Bagi perbankan hasil akhir penilaian kesehatan perbankan tersebut dapat digunakan sebagai salah satu sarana dalam menetapkan strategi uasaha di waktu yang akan datang, sedangkan bagi Bank Indonesia hasil dari penilaian kesehatan perbankan digunakan sebagai sarana penetapan dan implememtasi strategi pengawasan bank oleh Bank Indonesia.

Laba yang diraih dari kegiatan yang dilakukan merupakan cerminan kinerja sebuah perusahaan dalam menjalankan usahanya. Profitabilitas sebagai salah satu acuan dalam mengukur besarnya laba menjadi begitu penting untuk mengetahui apakah perusahaan telah menjalankan usahanya secara efisien, karena efisiensi baru dapat diketahui dengan membandingkan laba yang diperoleh dengan 
aktiva atau modal yang menghasilkan laba tersebut dengan kata lain adalah menghitung profitabilitas.

Pengertian Non Performing Loan menurut Mahmoedin (2001:2) adalah kredit yang tidak menepati jadwal angsuran sehingga terjadi tunggakan. Dari pengertian diatas dapat diambil kesimpulan bahwa suatu kredit dikategorikan sebagai kredit bermasalah bila tidak kembali sesuai jangka waktu yang diperjanjikan atau kesepakatan. Jika tidak ditangani dengan baik maka kredit bermasalah akan menjadi penyebab kerugian suatu bank. Kredit bermasalah tinggi merupakan kelemahan dalam kondisi neraca kualitas aset kredit yang buruk, dan kerentanan bank (Li Hua et al., 2008:871).

Sebuah perusahaan diwajibkan untuk mempertahankan likuiditasnya serta menjamin kelancaran operasi dalam memenuhi kewajibannya. Bank yang memiliki total aset besar, mempunyai kesempatan untuk menyalurkan kreditnya kepada pihak peminjam dalam jumlah yang lebih besar, sehingga memperoleh keuntungan yang tinggi (Alper, et al.,2011). Loan to Deposit Ratio merupakan ukuran kemampuan bank dalam membayar kembali penarikan dana yang dilakukan deposan dengan mengandalkan kredit yang diberikan sebagai sumber likuiditasnya (Dendawijaya, 2003).

Pengelolaan likuiditas merupakan salah satu masalah yang kompleks dalam kegiatan operasional bank, hal tersebut dikarenakan dana yang dikelola bank sebagian besar adalah dana dari masyarakat yang sifatnya jangka pendek dan dapat ditarik sewaktu-waktu. Likuiditas suatu bank berarti bahwa bank tersebut memiliki sumber dana yang cukup tersedia untuk memenuhi semua kewajiban 
(Siamat, 2005). Rasio likuiditas yang lazim digunakan dalam dunia perbankan terutama diukur dari Loan to Deposit Ratio.

Capital Adequacy Ratioadalah kecukupan modal yangmenunjukkan kemampuan bank dalam mempertahankan modalyang mencukupi dan kemampuan manajemen bank dalammengidentifikasi, mengukur, mengawasi, dan mengontrol risiko-risiko yang timbul yang dapat berpengaruh terhadap besarnya modal. Menipisnya tingkat kecukupan modal diakibatkan oleh banyaknya kredit yang mengalami masalah atau kredit macet juga dapat menyebabkan turunnya profitabilitas suatu bank (Bandwan, 2004).

Credit risk adalah risiko yang dihadapi bank karena menyalurkan dananya dalam bentuk pinjaman kepada masyarakat (Susilo, 2000). Seorang investor berani mendirikan bank, maka harus berani pula menanggung risiko kesulitan menagih kredit yang diberikan kepada debitur tertentu (Savitri,dkk.,2013). Rasio Non Performing Loan menunjukkan kemampuan manajemen bank dalam mengelola kredit bermasalah yang diberikan oleh bank. Semakin tinggi rasio Non Performing Loan maka semakin buruk kualitas kredit yang menyebabkan jumlah kredit bermasalah semakin besar sehingga dapat menyebabkan kemungkinan suatu bank dalam kondisi bermasalah semakin besar. Maka dalam hal ini semakin tinggi rasio Non Performing Loan maka semakin rendah profitabilitas suatu bank.

Hasil dari penelitian yang dilakukan oleh penelitian Azeem (2014) mengatakan bahwa Non Performing Loan berdampak negatif terhadap pada profitabilitas. Selanjutnya dari Agustiningrum (2013) yang mengatakan bahwa NPL berpengaruh negatif terhadap profitabilitas. Berdasarkan uraian tersebut, 
maka hipotesis mengenai hubungan Non Performing Loan terhadap Return On Asset adalah:

$\mathrm{H}_{1}$ : Non Performing Loan berpengaruh negatif terhadap Return On Asset.

Loan to Deposit Ratio adalah rasio antara seluruh jumlah kredit yang diberikan terhadap dana pihak ketiga.Loan to Deposit Ratio adalah ukuran seberapa jauh kemampuan bank dalam membiayai kembali penarikan dana yang dilakukan deposan dengan mengandalkan kredit yang diberikan sebagai sumber likuiditasnya. Semakin tinggi Loan to Deposit Ratio maka laba perusahaan semakin meningkat (dengan asumsi bank tersebut mampu menyalurkan kredit dengan efektif, sehingga jumlah kredit macetnya akan kecil). Dilihat dari sisi pengeluaran dana dalam bentuk kredit yang relatif tinggi dibandingkan dengan deposito atau simpanan masyarakat akan memberikan konsekuensi semakin besarnya risiko yang ditanggung oleh bank. Bank yang bersangkutan akan mengalami kesulitan untuk mengembalikan dana yang dititipkan oleh masyarakat. Agustiningrum (2013) juga menyatakan bahwa Loan to Deposit Ratio berpengaruh positif terhadap profitabilitas. Selanjutanya penelitian yang dilakukan oleh Syamsul (2012) juga menyatakan bahwa Loan to Deposit Ratio berpengaruh positif terhadap Return On Asset.Berdasarkan uraian tersebut, maka hipotesis mengenai hubungan Loan to Deposit Ratio terhadap Return On Asset adalah:

$\mathrm{H}_{2}$ : Loan to Deposit Ratio berpengaruh positif terhadap Return On Asset.

Capital Adequacy Ratio juga biasa disebut sebagai rasio kecukupan modal, yang berarti jumlah modal sendiri yang diperlukan untuk menutup risiko kerugian 
yang timbul dari penanaman aktiva-aktiva yang mengandung risiko serta membiayai seluruh benda tetap dan inventaris bank. Seluruh bank yang ada di Indonesia diwajibkan untuk menyediakan modal minimum sebesar $8 \%$ dari ATMR. Semakin besar Capital Adequacy Ratio maka keuntungan bank juga semakin besar. Dengan kata lain, semakin kecil risiko suatu bank maka semakin besar keuntungan yang diperoleh bank (Kuncoro dan Suharjono, 2002).

Menurut Dendawijaya (2003), Capital Adequacy Ratio adalah rasio yang memperlihatkan seberapa jauh seluruh aktiva bank yang mengandung risiko (kredit, penyertaan surat berharga, tagihan pada bank lain) ikut dibiayai dari dana modal sendiri bank disamping memperoleh dana-dana dari sumber-sumber diluar bank, seperti dana masyarakat, pinjaman (utang), dan lain-lain. Dengan kata lain, Capital Adequacy Ratio adalah rasio kinerja bank untuk mengukur kecukupan modal yang dimiliki bank untuk menunjang aktiva yang mengandung atau menghasilkan risiko, misalnya kredit yang diberikan. Capital Adequacy Ratio menunjukkan sejauh mana penurunan asset bank yang masih dapat ditutup oleh equity bank yang tersedia, semakin tinggi Capital Adequacy Ratio maka semakin baik kondisi bank (Tarmidzi, 2003). Penelitian yang dilakukan oleh Suka Negara dan Desy Natalia (2016) menyatakan bahwa Capital Adequacy Ratio tidak berpengaruh terhadap Return On Asset. Hal ini menunjukan bahwa peran kecukupan modal bank dalam menjalankan usaha pokoknya, tidak terlalu mempengaruhi Return On Asset. Dari penelitian yang dilakukan oleh I putu Gede Narayana (2013) yang hasilnya bahwa capital adequacy ratio berpengaruh positif signifikan terhadap return on asset, Y. Widi Kurnia Adityantoro (2013) yang 
hasilnya Capital Adequacy Ratio berpengaruh positif dan signifkan terhadap Return On Asset. Berdasarkan uraian tersebut, maka hipotesis mengenai hubungan Capital Adequacy Ratio terhadap Return On Asset adalah:

$\mathrm{H}_{3}$ : Capital Adequacy Ratio berpengaruh positif terhadap Return On Asset

\section{METODE PENELITIAN}

Penelitian ini dilakukan di perusahaan perbankan yang terdaftar di Bursa Efek Indonesia tahun 2014-2016 yang diakses melalui situs resmi Bursa Efek Indonesia (www.idx.co.id). Pendekatan yang digunakan dalam dalam penelitian ini adalah pendekatan kuantitatif, karena dalam penelitian in menggunakan variabel yang nanti akan dilakukan uji hipotesis. Penelitian ini menggunakan laporan keuangan dari Perusahaan Perbankan yang Terdaftar di Bursa Efek Indonesia. Desain penelitian ini berbentuk penelitian asosiatif dengan hubungan kasual. Objek penelitian dalam penelitian ini adalah return on assets pada sektor perbankan di Bursa Efek Indonesia. Return On Asset ini diduga dipengaruhi oleh non performing loan, loan to deposit ratio, dan capital adequacy ratio. Jenis data yang dipakai pada penelitian ini yaitu data kuantitatif. Data kuantitatif merupakan data yang dapat dinyatakan dalam bentuk angka-angka (Sugiyono, 2014: 12). Data yang digunakan dalam penelitian ini adalah laporan keuangan tahunan perusahaan perbankan yang terdaftar di Bursa Efek Indonesia (BEI) selama periode 20142016 yang diunduh di website Bursa Efek Indonesia (www.idx.co.id). Pada penelitian ini sumber data yang digunakan dalam penelitian ini adalah data sekunder yang dapat diperoleh dari laporan keuangan perusahaan perbankan yang 
terdaftar di Bursa Efek Indonesia tahun 2014-2016 yang dapat di unduh melalui website (www.idx.co.id).

Pada penelitian ini metode yang digunakan adalah metode observasi non partisipan yaitu metode teknik pengumpulan data dengan cara membaca, mengamati, mencatat, dan mempelajari uraian-uraian dari laporan keuangan tahunan (Sugiyono, 2014: 405). Rasio profitabilitas dapat dihitung dengan metode Return On Asset. Return On Asset merupakan perbandingan antara laba sebelum pajak dengan total asset. Return On Asset mengukur kemampuan bank dalam memperoleh laba dengan menggunakan aktiva yang dimilikinya. Dalam penelitian ini rasio Return On Asset yang digunakan adalah Return On Asset pada laporan keuangan pada Perusahaan Perbankan yang terdaftar di Bursa Efek Indonesia (BEI) periode 2014-2016. Return On Asset dinyatakan dalam persen (\%). Rumus Return On Asset menurut Surat Edaran Bank Indonesia No. 13/24/DPNP/2011 :

Return On Asset $=\frac{\text { Laba Sebelum Pajak }}{\text { Total Asset }} \times 100 \%$

Non Performing Loan merupakan perbandingan antara kredit kurang lancar, diragukan dan macet dengan total kredit yang telah diberikan. Rasio Non Performing Loan yang digunakan yaituNon Performing Loan pada laporan keuangan pada Perusahaan Perbankan yang terdaftar di Bursa Efek Indonesia (BEI) periode 2014-2016. Non Performing Loan dinyatakan dalam persentase (\%). Rumus Non Performing Loan menurut Surat Edaran Bank Indonesia No. 13/24/DPNP/2011:

Non Performing Loan $=\frac{\text { Kredit Bermasalah }}{\text { Total } \text { Kredit }} \times 100 \%$ 
Loan to Deposit Ratio adalah perbandingan antara total kredit yang telah diberikan oleh bank dengan total dana pihak ketiga yang dapat dihimpun oleh bank. Dalam penelitian ini rasio Loan to Deposit Ratio yang digunakan adalah Loan to Deposit Ratio pada laporan keuangan pada Perusahaan Perbankan yang terdaftar di Bursa Efek Indonesia periode 2014-2016. Loan to Deposit Ratio dinyatakan dalam persen (\%). Rumus Loan to Deposit Ratio menurut Surat Edaran Bank Indonesia No.13/24/DPNP/2011:

$$
\text { Loan to Deposit Ratio }=\frac{\text { Total Kredit }}{\text { Total dana Pihak Ketiga }} \times 100 \%
$$

Capital Adequacy Ratio merupakan perbandingan antara jumlah modal dengan aktiva tertimbang menurut risiko. Berdasarkan Peraturan Otoritas Jasa Keuangan Nomor 15/POJK.03/2017, permodalan minimum yang harus dimiliki oleh suatu bank adalah 8\%. Rasio Capital Adequacy Ratio yang digunakan Capital Adequacy Ratio pada laporan keuangan pada Perusahaan Perbankan yang terdaftar di Bursa Efek Indonesia (BEI) periode 2014-2016. Capital Adequacy Ratio dinyatakan dalam persen $(\%)$. Rumus CAR menurut Surat Edaran Bank Indonesia No.13/24/DPNP/2011:

$$
C A R=\frac{(\text { Modal Inti }+ \text { Modal Pelengkap })}{\text { Aktiva tertimbang menurut resiko }(\text { ATMR })} \times 100 \%
$$

Statistik deskriptif digunakan untuk memberikan informasi mengenai karakteristik penelitian terkait dengan nilai minimum. Nilai maksimum, nilai ratarata dan standar deviasi (Ghozali, 2013:23). Uji asumsi klasik adalah syarat uji yang digunakan dalam penelitian sebelum melakukan uji regresi. Model regresi dapat dikatakan baik apabila model tersebut bebas dari asumsi klasik statistik. Suatu model secara teoritis akan menghasilkan nilai parameter penduga yang tepat 
bila memenuhi persyaratan asusmsi klasik. Uji normalitas bertujuan untuk menguji apakah model regresi memiliki distribusi normal atau tidak. Model regresi yang baik adalah model regresi yang memiliki distribusi residual normal atau yang mendekati normal. Jika asumsi ini dilanggar, model regresi tidak valid terutama pada sampel kecil. Uji normalitas data dilakukan dengan uji Kolmogorov-Smirnov. Untuk mempermudah dalam melakukan perhitungan secara statistik, maka analisis yang dilakukan dalam penelitian ini akan diolah dengan bantuan software statistik SPSS 17.0 for Windows. Suatu data yang dinyatakan berdistribusi normal jika nilai Asymp Sig (2-tailed) hasil perhitungan Kolmogorov-Smirnov lebih besar dari 0,05 (Ghozali,2013:165). Uji Multikolinearitas bertujuan untuk menguji apakah model regresi ditemukan adanya korelasi antar variabel independen (Ghozali,2013:105). Model regresi yang baik seharusnya tidak terjadi kolerasi di antara variabel independen. Untuk mendeteksi ada atau tidaknya multikolinearitas di dalam model regresi pada penelitian ini menggunakan besaran VIF (Variance Inflation Factor) dan Tolerance. Nilai cut off yang umumnya dipakai untuk menunjukkan ada tidaknya multikolinearitas adalah nilai VIF dibawah 10 atau nilai tolerance diatas 0,10 . Uji Heteroskedastisitas bertujuan untuk menguji apakah dalam model regresi terjadi ketidaksamaan varians dari residual satu pengamatan ke pengamatan yang lain. Jika varians dari residual satu pengamatan ke pengamatan yang lain tetap, maka disebut homoskedastisitas dan jika berbeda disebut heteroskedastisitas. Model regresi yang baik adalah terbebas dari heteroskedastisitas. Uji heteroskedastisitas dilakukan dengan menggunakan uji Glejser, yang dilakukan dengan meregresikan 
nilai absolut residual yang diperoleh dari model regresi sebagai variabel dependen terhadap semua variabel independen dalam model regresi. Apabila nilai koefisien regresi dari masing-masing variabel bebas dalam model regresi ini tidak signifikan secara statistik, maka dapat disimpulkan tidak terjadi heteroskedastisitas (Ghozali, 2013:143). Dalam hal ini berarti sig nilai absolut residual> 0,05 untuk bebas dari heteroskedastisitas. Uji Autokorelasi bertujuan untuk menguji model regresi linier apakah ada korelasi kesalahan pengganggu pada periode $\mathrm{t}$ dengan kesalahan pada periode $\mathrm{t}-1$ atau tidak. Autokorelasi muncul karena observasi dilakukan dengan urutan waktu berkaitan satu sama. Model regresi yang baik adalah model yang bebas dari autokorelasi (Ghozali, 2013:110). Uji autokorelasi dilakukan dengan Uji Durbin Watson (DW-test) atau d statistik. Model regresi bebas dari autokorelasi jika hasil d statistik lebih besar dari batas atas $\left(\mathrm{d}_{\mathrm{u}}\right)$ dan kurang dari 4- $\mathrm{d}_{\mathrm{u}}$. Pengujian hipotesisi menggunakan analisis regresi linier berganda. Analisis regresi linier berganda adalah analisis yang menggambarkan kenaikan atau penurunan variabel independen terhadap variabel dependen. Penelitian ini menggunakan analisis linier berganda untuk menganalisis Pengaruh Non Performing Loan, Loan to Deposit Ratio dan Capital Adequacy Ratio terhadap Return On Asset dengan menggunakan alat analisis SPSS 17. Bentuk umum model penelitian ini yaitu,

$$
Q=\alpha+\beta_{1} X_{1}+\beta_{2} X_{2}+\beta_{3} X_{3}+e
$$

Keterangan:

$\begin{array}{ll}\mathrm{Q} & \text { : Return On Asset (ROA) } \\ \mathrm{X}_{1} & \text { : Non Performing Loan (NPL) } \\ \mathrm{X}_{2} & \text { : Loan to Deposit Ratio (LDR) } \\ \mathrm{X}_{3} & \text { : Capital Adequacy Ratio (CAR) }\end{array}$




$$
\begin{array}{ll}
\alpha & : \text { Nilai Konstanta } \\
\beta_{1}-\beta_{2} & : \text { Koefisien Regresi } \\
\mathrm{e} & : \text { eror }
\end{array}
$$

\section{HASIL DAN PEMBAHASAN}

Statistik deskriptif disajikan untuk memberikan informasi mengenai karakteristik variabel-variabel penelitian, antar yang lain rata-rata dan standar deviasi. Adapun hasil statistik deskriptif dapat dilihat pada tabel 1 berikut.

Tabel 1.

Hasil Statistik Deskriptif (dalam persentase \%)

\begin{tabular}{cccccc}
\hline & N & Minimum & Maximum & Mean & Std. Deviation \\
\hline ROA & 60 & -3.34 & 3.36 & 0.9822 & 0.92161 \\
NPL & 60 & 0.00 & 3.33 & 1.2583 & 0.79690 \\
LDR & 60 & 50.27 & 99.88 & 82.8978 & 12.89749 \\
CAR & 60 & 6.82 & 42.23 & 25.3623 & 11.35960 \\
Valid N (listwise) & 60 & & & & \\
\hline
\end{tabular}

Sumber : data diolah, 2018

Nilai minimum return on asset sebesar $-3,34$ artinya kemampuan terendah bank memperoleh laba dari total aktiva yang dimiliki yaitu mengalami kerugian sebesar 3,34\%. Nilai maksimum 3,36 artinya kemampuan maksimal bank dalam memperoleh laba melalui pemanfaatan aktiva yang dimilikinya adalah sebesar $3,36 \%$. Nilai rata-rata sebesar 0,9822 bermakna rata-rata kemampuan bank dalam memperoleh keuntungan melalui pemanfaatan aktiva yang dimiliki yaitu sebesar $0,9822 \%$.

Non Performing Loanmemiliki nilai minimum sebesar 0,00 artinya dari total kredit yang diberikan tidak terdapat kredit bermasalah. Nilai maksimum sebesar 3,33 berartidari total kredit yang diberikan, kredit bermasalah tertinggi bank yaitu sebesar 3,33\%. Rata-rata Non Performing Loan adalah 1,2583 bermakna bank mengalami kredit bermasalah rata-rata sebesar $1,2583 \%$ dari total kredit yang 
diberikan.

Loan to Deposit Ratiomemiliki nilai minimum sebesar 50,27 yang artinya total kredit terendah bank sebesar 50,27\% dari total dana pihak ketiga yang dimilikinya. Nilai maksimum sebesar 99,88 artinya total kredit tertinggi yang diberikan bank adalah sebesar $99,88 \%$ dari total dana pihak ketiga yang dimilikinya. Rata-rata variabel Loan To Deposit Ratio adalah 82,8978 bermakna perusahaan perbankan memberikan kredit rata-rata sebesar $82,8978 \%$ dari total dana pihak ketiga yang dimilikinya.

Capital Adequacy Ratiomemiliki nilai minimum sebesar 6,82 artinya bahwa bank memiliki modal yang cukup rendah untuk menanggung risiko kerugian sebesar $6,82 \%$ dari aktiva yang berisiko dan membiaya kegiatan operasional. Nilai maksimum sebesar 42,23 yang artinya bank memiliki modal yang cukup tinggi dalam menanggung risiko kerugian sebesar $42,23 \%$ dari aktiva yang berisiko dan membiayai kerugian operasionalnya bank. Rata-rata variabel Capital Adequacy Ratio adalah 25,3623 yang berarti dari aktiva yang berisiko dan membiayai kegiatan operasional,modal bank sanggup menanggung risiko kerugian sebesar $25,3623 \%$.

Uji normalitas bertujuan untuk menguji apakah dalam model regresi, variabel pengganggu atau residual memiliki distribusi normal atau tidak. Suatu model regresi dikatakan memiliki data normal atau mendekati normal jika koefisien Asymp.sig (2-tailed) lebih besar dari $\alpha=0,05$. Hasil uji normalitas dengan uji Kolmogorov-Smirnov diperoleh 0,314 sehingga data yang akan dianalisis berdistribusi normal. Hasil uji Kolmogorov-Smirnov dapat dilihat pada Tabel 2 
sebagai berikut :

Tabel 2

Hasil Uji Normalitas

\begin{tabular}{ccr}
\hline & & $\begin{array}{c}\text { Unstandardized } \\
\text { Residual }\end{array}$ \\
\hline Normal Parameters ${ }^{\mathrm{a}, \mathrm{b}}$ & Mean & 60 \\
Most Extreme & Std. Deviation & .0296723 \\
Differences & Absolute & .15639699 \\
Kolmogorov-Smirnov Z & Positive & -.154 \\
Asymp. Sig. (2-tailed) & Negative & 1.193 \\
\hline Sumber $:$ data diolah, 2018 & & $.116^{\mathrm{c} \mathrm{d}}$ \\
\hline
\end{tabular}

Teknik untuk mengetahui adanya multikolinearitas dalam model regresi adalah terkait dari nilai tolerance dan variance inflation factor (VIF). Pada Tabel dibawah ini disajikan hasil perhitungan nilai tolerance dan VIF kurang dari angka 10 dan angka tolerance lebih dari 0,1 menggunakan program SPSS (Statistikal Package for the Social Sciens).

Tabel 3

Hasil Uji Multikolinearitas

\begin{tabular}{|c|c|c|c|}
\hline & & \multicolumn{2}{|c|}{ Collinearity Statistics } \\
\hline \multicolumn{2}{|c|}{ Model } & Tolerance & VIF \\
\hline \multirow[t]{3}{*}{1} & NPL & .970 & 1.031 \\
\hline & LDR & .946 & 1.057 \\
\hline & CAR & .964 & 1.038 \\
\hline
\end{tabular}

Tabel 3 menunjukkan bahwa tidak ada multikolinearitas antara variabel bebas dalam model regresi, di mana nilai tolerance diatas dari 0,1 atau nilai VIF 
dibawah dari 10.

Ujiheteroskedastisitas dilakukan dengan menggunakan uji Glejset. NilaiAsymp. Sig ( $p$ value $)>0,05$ bermakna tidak terjadi heteroskedastisitas. Hasil uji heteroskedastisitas disajikan pada Tabel 4sebagai berikut:

\section{Hasil Uji Heteroskedastisitas}

\begin{tabular}{|c|c|c|c|c|c|c|}
\hline & \multirow[b]{2}{*}{ Model } & \multicolumn{2}{|c|}{$\begin{array}{l}\text { Unstandardized } \\
\text { Coefficients }\end{array}$} & \multirow{2}{*}{$\begin{array}{c}\begin{array}{c}\text { Standardized } \\
\text { Coefficients }\end{array} \\
\text { Beta } \\
\end{array}$} & \multirow[b]{2}{*}{$\mathbf{T}$} & \multirow[b]{2}{*}{ Sig. } \\
\hline & & B & Std. Error & & & \\
\hline \multirow[t]{4}{*}{1} & (Constant) & .7122 & .5575 & & 1.2774 & .2067 \\
\hline & NPL & .0369 & .0960 & .0504 & .3839 & .7025 \\
\hline & LDR & .0004 & .0060 & .0095 & .0718 & .9430 \\
\hline & CAR & -.0124 & .0068 & -.2424 & -1.8408 & .0709 \\
\hline
\end{tabular}

Sumber: data diolah, 2018

Berdasarkan Tabel 4, diketahui seluruh variabel memiliki Asymp. Sig ( $p$ value $)>0,05$, berarti pada model regresi tidak terjadi heteroskedastisitas.

Uji autokolerasi dilakukan untuk mendeteksi adanya kolerasi antara data pada masa sebelumnya $\left(\mathrm{t}_{-1}\right)$ dengan data sesudahnya $\left(\mathrm{t}_{1}\right)$. Model uji yang baik adalah terbebas autokolerasi. Autokolerasi dalam model regresidiidentifikasi dengan melakukan uji Durbin-Watson (DW). Jika nilai DW terletak antara nilai $\mathrm{d}_{\mathrm{u}}$ dan nilai 4 - $\mathrm{d}_{\mathrm{u}}$ maka data dikatakan bebas autokolerasi. Hasil Uji autokolerasi disajikan pada Tabel 5 sebagai berikut:

Tabel 5

Hasil Uji Autokorelasi

\begin{tabular}{cccccc}
\hline Model & R & R Square & $\begin{array}{c}\text { Adjusted R } \\
\text { Square }\end{array}$ & $\begin{array}{c}\text { Std. Error of the } \\
\text { Estimate }\end{array}$ & $\begin{array}{c}\text { Durbin- } \\
\text { Watson }\end{array}$ \\
\hline 1 & $.618^{\text {a }}$ & .382 & .349 & .74382 & 1.734 \\
\hline Sumber $:$ data diolah, 2018 & & & &
\end{tabular}

Tabel 5 menunjukkan nilai DW sebesar 2,023. Data sampel $(n)=60$ dan 
jumlah variabel bebas $(k)=3$ serta $\alpha=5 \%$ diperoleh angka $d_{L}=1,480$ dan $d_{u}=$ 1,689 sehingga diperoleh juga nilai4 $-\mathrm{d}_{\mathrm{u}}=2,311$. Nilai DW sebesar 1,734 terletak antara nilai $d_{u}=1,689$ dan $4-d_{u}=2,311$ sehingga menunjukkan data yang digunakan pada penelitian ini bebas dari autokorelasi.

Berdasarkan pengujian asumsi klasik diatas, dapat disimpulkan bahwa model regresi lolos dari uji asumsi klasik. Model yang digunakan dalam menganalisis variabel-variabel yang mempengaruhi return on assets adalah model analisis regresi linear berganda dengan bantuan program SPSS. Dalam model analisis regresi linear berganda yang menjadi variabel terikatnya adalah return on assets, sedangkan variabel bebaspenelitian yaitunon performing loan, loan to deposit ratio, capital adequacy ratio. Hasil Regresi Linier Berganda disajikan pada tabel 6. Sesuai dengan hasil analisis regresi pada Tabel 6 dapat disusun persamaan regresi sebagai berikut:

$\mathrm{Y}=0,314-0,608 \mathrm{X}_{1}+0,023 \mathrm{X}_{2}-0,019 \mathrm{X}_{3}+\mathrm{e}$

\section{Tabel 6}

Hasil Uji Analisis Regresi Linear Berganda

\begin{tabular}{|c|c|c|c|c|c|c|}
\hline & \multirow[b]{2}{*}{ Model } & \multicolumn{2}{|c|}{ Unstandardized Coefficients } & \multirow{2}{*}{$\begin{array}{c}\begin{array}{c}\text { Standardized } \\
\text { Coefficients }\end{array} \\
\text { Beta }\end{array}$} & \multirow[t]{2}{*}{$\mathbf{T}$} & \multirow{2}{*}{ Sig. } \\
\hline & & B & Std. Error & & & \\
\hline \multirow[t]{4}{*}{1} & (Constant) & .314 & .717 & & .438 & .663 \\
\hline & NPL & -.608 & .123 & -.526 & -4.925 & .000 \\
\hline & LDR & .023 & .008 & .322 & 2.977 & .004 \\
\hline & CAR & -.019 & .009 & -.229 & -2.141 & .037 \\
\hline
\end{tabular}

Berdasarkan model regresi dan tabel 6 diatas maka hasil regresi berganda dapat dijelaskan yaitu persamaan regresi linear berganda diatas, diketahui mempunyai konstanta sebesar 0,314 dengan dengan tanda positif. Sehingga besaran konstanta menunjukkan bahwa jika variabel-variabel independen (Non 
Putu Intan Trisna Dewi dan I Ketut Suryanawa.Pengaruh...

Performing Loan, Loan to Deposit Ratio, dan Capital Adequacy Ratio) diasumsikan konstan, maka variabel dependen yaitu Return On Asset akan naik sebesar 0,314\%.Koefisien variabel Non Performing Loan sebesar -0.608 artinya jika Non Performing Loan mengalami kenaikan sejumlah 1\%, maka Return On Asset akan menurun sejumlah -0,608\%. Koefisien variabel Loan to Deposit Ratio yaitu sebesar 0,023 bermakna setiap kenaikan Loan to Deposit Ratio sebesar $1 \%$ maka Return On Asset akan mengalami kenaikan sebesar 0,023\%.Koefisien variabel Capital Adequacy Ratio sebesar -0,019 berarti setiap kenaikan Capital Adequacy Ratio sebesar $1 \%$ akan menyebabkan menurunnya Return On Asset sebesar $-0,019 \%$.

Uji kelayakan model $\mathrm{F}$ bertujuan untuk mengetahui kelayakan model regresi linear berganda sebagai alat analisis. Uji F dilakukan untuk mengetahui apakah semua variabel bebas antara lainnon performing loan, loan to deposit ratio dan capital adequacy ratio layak uji. Apabila hasil uji F menyatakan signifikansi $\mathrm{F}$ value $\leq \alpha=0,05$, maka hubungan antara variabel-variabel bebas adalah signifikan terhadap return on assets dan model regresi yang digunakan dianggap layak uji. Hasil analisis kelayakan model (F) ini dapat dilihat pada tabel 7 sebagai berikut:

\section{Tabel 7}

Hasil Analisis Kelayakan Model (Uji F)

\begin{tabular}{cccrrrr}
\hline & & Sum of & & & \\
& Model & Squares & Df & Mean Square & F & Sig. \\
\hline 1 & Regression & 19.130 & 3 & 6.377 & 11.525 & $.000^{\text {a }}$ \\
Residual & 30.983 & 56 & .553 & & \\
Total & 50.113 & 59 & & &
\end{tabular}

Sumber: data diolah, 2018 
Tabel 7 menunjukkan nilai $\mathrm{F}$ hitung sebesar 11,525 dengan signifikan $\mathrm{F}$ atau $p$ value sebesar 0,000 lebih kecil dari nilai $\alpha=0,05$. Hal ini menunjukkan bahwa model persamaan dalam penilitian ini layak digunakan.

Uji parsial (uji t) digunakan untuk menguji pengaruh masing-masing variabel bebas (Non performing loan, Loan to deposit ratio dan Capital adequacy ratio) terhadap variabel terikat (Return on assets). Hasil pengujian secara parsial masing-masing variabel bebas terhadap variabel terikat dapat dijelaskan sebagai berikut:

Berdasarkan pengaruh Non Performing Loan terhadap Return On Assets Tabel 6 terlihat bahwa besar nilai $t_{\text {hitung }}$ sebesar $-4,925$ dengan taraf siginifikansi yaitu 0,000 lebih kecil dari taraf $\alpha=0,05$. Karena $t_{\text {hitung }}$ lebih kecil dari $-t_{\text {tabel }}(-$ 1,671) dan signifikansi $\mathrm{t} \leq \alpha=0,05$ ini berarti hipotesis pertama yang menyebutkan bahwa Non Performing Loan berpengaruh negatif terhadap Return On Assets diterima.

Berdasarkan Tabel 6 pengaruh Loan to Deposit Ratio terhadap Return On Assets terlihat bahwa besar $t_{\text {hitung }}$ sebesar 2,977 dengan taraf siginifikansi sebesar 0,004. Hasil signifikansi tersebut menunjukkan bahwa taraf signifikansi Loan to Deposit Ratio lebih kecil dari taraf $\alpha=0,05$. Karena thitung lebih besar dari tabel $(1,671)$ dan signifikansi $\mathrm{t} \leq \alpha=0,05$ ini berarti hipotesis kedua yang menyebutkan bahwa Loan to Deposit Ratio berpengaruh positif terhadap Return On Assets diterima.

Berdasarkan Tabel 6 pengaruh Capital Adequacy Ratio pada Return On Assetsterlihat bahwa besar nilai thitung sebesar -2,141 sedangkan taraf siginifikansi 
sebesar 0,037 ,yang lebih kecil dari taraf $\alpha=0,05$. Ini berarti hipotesis ketiga ditolak karenaCapital Adequacy Ratioterbukti berpengaruh negatif padaReturn On Assets.

Koefisien determinasi $\left(\mathrm{R}^{2}\right)$ pada intinya mengukur seberapa jauh kemampuan model dalam menerangkan variasi variabel dependen. Nilai koefisien determinasi adalah antara 0-1. Dari hasil output SPSS model summary yang dinyatakan dalam Tabel 5 menunjukkan untuk dapat mengetahui seberapa besar non performing loan, loan to deposit ratio dan capital adequacy ratio memengaruhi return on assets, dapat dilihat dari nilai koefisien adjusted $\mathrm{R}^{2}$ adalah 0,349 hal ini berarti $34,9 \%$ variasi return on assets dapat dijelaskan oleh variasi dari ketiga variabel independen antara lainnon performing loan, loan to deposit ratio dan capital adequacy ratio. Sedangkan sisanya 65,1\% (100\% - 34,9\%) dijelaskan oleh faktor lain diluar model.

\section{SIMPULAN}

Berdasarkan pada hasil analisis data dan pembahasan yang telah dipaparkan pada bab sebelumnya, maka dapat ditarik kesimpulan sebagai berikut:Non Performing loan berpengaruh negatif terhadap return on asset. Peningkatan kredit bermasalah akan berpengaruh terhadap return on asset dapat dilihat semakin tingginya kredit bermasalah maka return on asset akan mengalami penurunan. Loan to Deposit Ratio berpengaruh positif signifikan terhadap return on asset. Kinerja perbankan di BEI pada umumnya efisien, sehingga dapat memaksimalkan nilai pendapatan dari dana yang dipinjamkan kepada masyarakat. Capital Adequacy Ratio berpengaruh negatif signifikan terhadap return on asset. Modal digunakan untuk 
menutupi risiko kredit bermasalah dan penyaluran kredit yang setiap tahunnya meningkat, sehingga bank tidak memperoleh pendapatan bunga yang berarti retun on asset menurun.

Berdasarkan simpulan di atas, maka dapat dinyatakan beberapa saran sebagai berikut. Bagi pihak Perbankan harus lebih menerapkan prinsip kehati-hatiannya dalam pemberian dan penyaluran kredit, karena jika tidak diperhatikan aturan dalam pemberian dan penyaluran kredit berdampak pada likuiditas Perbankan dan meningkatkan presentase rasio kredit bermasalah. Bagi peneliti selanjutnya diharapkan penelitian ini digunakan sebagai referensi atau perbandingan bagi penelitian selanjutnya dengan menambahkan rasio keuangan lainnya yang dapat mempengaruhi return on asset dan dapat memperpanjang periode pengamatan agar memperoleh hasil yang lebih bervariatif.

\section{REFERENSI}

Agustiningrum, Rizki. 2013. Analisis Pengaruh Car, Npl, Dan Ldr Terhadap Profitabilitas Pada Perusahaan Perbankan. E-Jurnal Manajemen Universitas Udayana, 2(8): $h$ : 885-902.

Alper, Deger and Adem Anbar. 2011. Bank Specific And Macroeconomic Determinants Of Commercial Bank Profitability: Empirical Evidence From Turkey. Business and Economics Research Journal,2(2): pp: 139-152.

Anjani, Dewa Ayu dan Ni Ketut Purnawati. 2014. Pengaruh non performing loan (NPL), Likuiditas dan Rentabilitas Terhadap Rasio Kecukupan Modal. EJurnal Manajemen Universitas Udayana, 3 (4): h: 1140-1154.

Azeem, S. M. (2014). Job Satisfaction and Organizational Commitment amongEmployees in The Sultanate of Oman Psychology. Journal OrganizationalBehavior, Vol. 1, pp. 295-299.

Bank Indonesia. 2011. Surat Edaran Bi No. 13/24/DPNP Tanggal 25 Oktober 2011 tentang Penilaian Tingkat Kesehatan Bank Umum. Jakarta: Bank Indonesia. 
Dendawijaya dan Lukman. 2003. Manajemen Perbankan, Penerbit Ghalia Indonesia. Jakarta.

Ghozali, imam. (2013). Aplikasi analisis Multivariate dengan programSPSS,Semarang: Badan Penerbit UNDIP.

Idroes, Ferry N. 2011. Manajemen Risiko Perbankan, Pemahaman Pendekatan 3 Pilar Kesepakatan Basel II Terkait Aplikasi Regulasi dan Pelaksanaannya di Indonesia. Jakarta: RajawaliPers.

I Putu Gede Narayana. 2013. Pengaruh Perputaran kas, loan deposit ratio, tingkatpemodalan dan leverage terhadap propitabilitas bank perkereditan rakyat(BPR) sekota denpasar periode 2009-2011. E-jurnal akuntansi Universitas udayana 3.2(2013):334-350.ISSN: 2302-8556 ISSN :19794878

Kuncoro Mudrajat, Suhardjono. (2002). Manajemen Perbankan, Teori danAplikasi. Yogyakarta: BPFE .

Li-Hua Huang, Hsing-chin, Hsiao, Mei-Ai Cheng and Shyr-Juh Chang. 2008. Effects of Financial Reform On Productivity Change. Industrial Management \& Data System, 108(7) Pg:867-886

Mahmoedin, As. 2001. Melacak Kredit Bermasalah. Jakarta: Pustaka Sinar Harapan..

Manuaba, I B Pranabawa Adi Kencana. 2012. Pengaruh Capital Adequacy Ratio, Non Performing Loan, Ukuran Perusahaan Dan Struktur Kepemilikan Terhadap Profitabilitas Bank Yang Terdaftar Di BEI Tahun 2008-2011. EJurnal Akuntansi Universitas Udayana, 1(1).

Peraturan Otoritas Jasa Keuangan Nomor. 15/POJK.03/2017. Tentang Penetapan Status dan Tindak Lanjut Pengawasan Bank Umum. Jakarta: Otoritas Jasa Keuangan.

Siamat, Dahlan. (2005). Manajemen Lembaga Keuangan. Jakarta: Fakultas Ekonomi Universitas Indonesia.

Sianturi, Maria Regina Rosario. 2012. Pengaruh Car, Npl, Ldr, Nim, Dan Bopo Terhadap Profitabilitas Perbankan (Studi Kasus Pada Bank Umum Yang Listed Di Bursa Efek Indonesia Tahun 2007-2011). Skripsi Jurusan Manajemen Pada Fakultas Ekonomi Dan Bisnis Universitas Hasanudin, Makasar.

Sugiyono, 2014. Metode Penelitian Bisnis. Bandung: Alfabeta 
Suka Negara dan Desy Natalia. 2016. Pengaruh Loan to Deposit Ratio dan Capital Adequacy Ratio Terhadap Profitabilitas Bank Umum Konvensional di Indonesia Tahun 2010-2014 dengan Non Performing Loan sebagai Variabel Pemoderasi. Skripsi. Universitas Hindu Indonesia.

Tarmizi Achmad \& Willyanto Kartiko Kusuno.(2003). "Analisis Rasio-Rasio Keuangan sebagai Indikator dalam Memprediksi PotensiKebangkrutan Perbankan di Indonesia”.'Media Ekonomi \& Bisnis. Vo.XV. No.1. Juni 2003.

Y. Widi Kurnia Adityantoro, Shiddiq Nur Rahardjo. 2013. Faktor- Faktor yangmempengaruhi profitabilitas perbankan di indonesia. ISSN :23323806. Diponogooro journal of accounting. 